\title{
DESKRIPSI JUMLAH DAN SPESIES TIKUS DI DESA BANJARPANEPEN KECAMATAN SUMPIUH KABUPATEN BANYUMAS
}

\author{
Vita Catelya Purbaningsih'), Arif Widyanto' ${ }^{2)}$ \\ Poltekkes Kemenkes Semarang, Poltekkes Kemenkes Semarang
}

\begin{abstract}
Abstrak
Asosiasi tikus dengan manusia seringkali bersifat parasitisme, tikus mendapatkan keuntungan sedangkan manusia sebaliknya. Tikus sering menimbulkan gangguan bagi manusia dalam berbagai hal. Di bidang kesehatan, tikus dapat menjadi sarana bagi beberapa patogen yang dapat menyababkan penyakit pada manusia dan hewan peliharaan. Penyakit yang ditularkan oleh tikus diantaranya adalah penyakit pes, salmonellosis, leptospirosis, scrub typhus, murine typhus, rat-bite fever. Tujuan dari penelitian ini antara lain mendeskripsikan kasus Leptospirosis di Desa Banjarpanepen, memasang perangkap tikus, menghitung jumlah tikus yang tertangkap, mengidentifikasi spesies tikus yang tertangkap. Metode penelitian yang digunakan observasional dengan analisis deskriptif. Data dikumpulkan secara langsung pada subyek penelitian. Analisis data di gunakan analisis tabel dan grafik yaitu dianalisis secara deskriptif.Hasil Trapping di Desa Banjarpanepen dengan Succes trap 16,5\%. Spesies tikus yang berhasil ditangkap di wilayah RT 1 RW 4 adalah Rattus tanezumi 13 ekor (76,47\%), Juvenile 4 ekor (0,24\%). Jenis tikus yang berhasil ditangkap di wilayah RT 1 RW 8 adalah Rattus tanezumi sejumlah 10 ekor (62,5\%), Juvenile (tikus muda) sejumlah 5 ekor (31,25\%), Subadult (tikus remaja) sejumlah 1 ekor (6,25\%). Simpulan dari penelitian ini diperoleh spesies tikus Rattus tanezumi. Tikus Rattus tanezumi merupakan tikus rumah dan tikus ini berperan penting dalam penularan beberapa penyakit seperti pes, dan leptospirosis. Disarankan untuk meningkatkan upaya pengendalian guna mencegah penyebaran habitat yang luas dan pemeriksaan bakteri Leptospira sp. pada tikus dan lingkungan serta hewan domestik dengan melibatkan dinas peternakan dan pertanian setempat sehingga dapat terdeteksi jalur penularan Leptospirosis di wilayah Desa Banjarpanepen.
\end{abstract}

Kata kunci : : Tikus; Leptospirosis

Abstract

The association of rodents with humans is often parasitic, rats benefit while humans do the opposite. Mice often cause disruption to humans in many ways. In the field of health, mice can be a means for some pathogens that can cause disease in humans and pets. Diseases that are transmitted by rats include pest, salmonellosis, leptospirosis, typhoid scrubs, murine typhus, rat-bite fever. The objectives of the study were to describe cases of leptospirosis in Banjarpanepen village, installing a mousetrap, counting the number of mice caught, identifying captured mice species.Research method used observasional with descriptive analysis. Data were collected directly on the research subjects. Analysis of data in the use of table and graph analysis is analyzed descriptively.Trapping Results in Banjarpanepen Village with Success trap $16.5 \%$. Species of rats successfully caught in RT 1 RW 4 were Rattus tanezumi 13 (76.47\%), Juvenile 4 (0.24\%). The types of rats that were successfully captured in RT 1 RW 8 were Rattus Tanezumi with 10 tail (62,5\%), Juvenile (young rats) 5 (31,25\%), Subadult (rats of teen) of 1 (6, 25\%). Conclusions from this study were obtained by rat species Rattus tanezumi. Ratus tanezumi is a house rat and this rat plays an important role in the transmission of several diseases such as plague, and leptospirosis. It is recommended to increase control measures to prevent widespread habitat spread and examination of Leptospira sp. in rodents and the environment and domestic animals involving local livestock and agricultural services so that a pathway of Leptospirosis can be detected in Banjarpanepen Village area.

Keywords $\quad$ : Rat, Leptospirosis

1) E-mail : vitacattleya@gmail.com

2) E-mail : arifwidyanto74@yahoo.com 


\section{PENDAHULUAN}

Pembangunan kesehatan pada periode 2015-2019 adalah Program Indonesia Sehat dengan sasaran meningkatkan derajat kesehatan dan status gizi masyarakat melalui upaya kesehatan dan pemberdayaan masyarakat yang didukung dengan perlindungan finansial dan pemeratan pelayanan kesehatan. Sasaran pokok RPJMN 2015-2019 adalah: (1) meningkatnya status kesehatan dan gizi ibu dan anak; (2) meningkatnya pengendalian penyakit; (3) meningkatnya akses dan mutu pelayanan kesehatan dasar dan rujukan terutama di daerah terpencil, tertinggal dan perbatasan; (4) meningkatnya cakupan pelayanan kesehatan universal melalui Kartu Indonesia Sehat dan kualitas pengelolaan SJSN Kesehatan, (5) terpenuhinya kebutuhan tenaga kesehatan, obat dan vaksin; serta (6) meningkatkan responsivitas sistem kesehatan. (Rencana Strategis Kementerian Kesehatan Tahun 20152019, h.6).

Derajat kesehatan yang optimal dapat terwujud bila dilakukan upaya kesehatan melalui pendekatan pemeliharaan kesehatan (promotif), pencegahan penyakit (preventif), penyembuhan penyakit (kuratif), dan pemulihan penyakit (rehabilitatif) yang dilakukan secara menyeluruh, terpadu dan berkesinambungan. Salah satu upaya pencegahan penyakit dapat dilakukan melalui peningkatan kesehatan lingkungan dengan usaha pemberantasan binatang pengganggu seperti tikus. Penyakit yang ditularkan oleh tikus diantaranya adalah penyakit pes, salmonellosis, leptospirosis, scrub typhus, murine typhus, rat-bite fever.

Asosiasi tikus dengan manusia seringkali bersifat parasitisme, tikus mendapatkan keuntungan sedangkan manusia sebaliknya. Tikus sering menimbulkan gangguan bagi manusia dalam berbagai hal. Di bidang pertanian, tikus sering menjadi ancaman bagi pengelola pertanian di dalam usaha budi dayanya, baik itu pada komoditas pangan, perkebunan, maupun hortikultura. Di bidang peternakan, tikus sering mengganggu ternak ayam, kambing, sapi, dan sebagainya terutama dalam hal mengambil pakannya. Di bidang rumah tangga, tikus seringkali membuat keonaran dan menimbulkan kotoran pada bagian tertentu dari ruangan kita. Di bidang kesehatan, tikus dapat menjadi sarana bagi beberapa patogen yang dapat menyababkan penyakit pada manusia dan hewan peliharaan. (Swastiko Priyambodo, 1995, h.2).
Pes menurut International Health Regulation termasuk dalam Public Health Emergencies of International Concern (PHEIC) dan merupakan jenis penyakit menular yang dapat menimbulkan wabah (Depkes RI, 2008). Pes merupakan penyakit zoonosis terutama pada tikus dan Rodent lain yang dapat ditularkan kepada manusia. Penyakit yang dikenal dengan nama pesteurellosis atau yersiniosis/plague/sampar ini bersifat akut disebabkan oleh bakteri Yersinia pestis (Pesteurella pestis) (Ditjen PPM \& PL, Depkes RI, 2000).

Di Indonesia terdapat empat propinsi yang menjadi daerah pengawasan pes, yaitu di Ciwidey Kabupaten Bandung (Jawa Barat), Cangkringan Kabupaten Sleman (Yogyakarta), di Kecamatan Tutur, Tosari, Puspo, dan Pasrepan Kabupaten Pasuruan (Jawa Timur), dan di Kabupaten Boyolali di Kecamatan Selo dan Cepogo, (Jawa Tengah) (Sub Direktorat Zoonosis, 2008).

Hasil penelitian sebelumnya yang dilakukan oleh Aziz Awaludin di Perumahan Griya Bukateja Baru Desa Kedungjati pada tahun 2011 diperoleh 19 ekor tikus dengan 3 spesies yaitu Rattus-rattus diardii, Bandicota indica, dan Rattus norvegicus, serta diperoleh 22 ekor pinjal dari tikus yang tertangkap dengan 2 spesies yaitu Xenopsylla cheopis dan Neopsylla sondaica. Kemudian untuk inspeksi sanitasi rumah sehat diperoleh 4 atau $17 \%$ masuk dalam kriteria rumah sehat, dan 19 rumah atau $83 \%$ dalam kriteria rumah tidak sehat.

Tikus merupakan binatang mamalia yang sering kita jumpai di sekitar kita. Binatang pengerat ini identik dengan lingkungan kotor dan penyakit yang berdampak merugikan manusia. Kerugian yang disebabkan oleh tikus antara lain bisa merusak dan menghabiskan makanan, tanaman, barang dan bahkan bahan bangunan.

Tikus sering membuat lubang atau terowongan di daerah permukiman manusia. Dengan demikian perpindahan penyakit yang dibawa tikus kepada manusia terbilang cukup besar, baik gigitan yang dilakukan oleh tikus ataupun melalui gigitan vektor yang menempel pada tubuh binatang tersebut, antara lain adalah pinjal. Penyakit yang ditimbulkan tidak hanya karena pinjal saja, tetapi juga urine tikus yang menyebabkan penyakit Leptospirosis yang penularannya bisa terjadi pada saat banjir karena kencing tikus ikut terbawa oleh air sehingga bisa menular ke orang yang sehat. Penyakit Leptospirosis penularannya bisa juga melalui makanan dan atau minuman yang sudah 
kontak dengan urine tikus yang mengandung bakteri Leptospira. sp.

Di Kabupaten Banyumas ditemukan kasus Leptospirosis sebanyak 66 kasus dan tercatat 8 angka kematian pada tahun 2017. Kasus tersebut diantaranya terletak pada Kecamatan Banyumas yang tercatat 2 kematian, Kecamatan Cilongok 2 kematian, dan terbanyak pada Kecamatan Sumpiuh yaitu 4 kematian. Kasus Leptospirosis di Kecamatan Sumpiuh tercatat 9 kasus dengan 4 angka kematian yang tepatnya berada di Desa Banjarpanepen yaitu 2 kematian dan 1 kematian berada di Desa Ketanda dan Desa Boganging. Oleh karena itu berdasarkan latar belakang permasalahan di atas, peneliti tertarik dan bermaksud ingin melakukan penelitian terkait dengan jumlah dan spesies tikus serta penyebab penyakit yang ditularkannya dengan judul "Deskripsi Jumlah dan Spesies Tikus Di Desa Banjarpanepen Kecamatan Sumpiuh Kabupaten Banyumas Tahun 2018".

\section{BAHAN DAN METODE}

Jenis penelitian ini termasuk penelitian deskriptif yang bertujuan memperoleh gambaran tentang jumlah dan spesies tikus di Desa Banjarpanepen, Kecamatan Sumpiuh, Kabupaten Banyumas.

Subyek penelitian ini adalah program pengendalian tikus yang dilakukan di Desa Banjarpanepen, Kecamatan Sumpiuh, Kabupaten Banyumas.

Data yang diperlukan dalam penelitian ini adalah data primer yang meliputi spesies tikus dan jumlah tikus (succes trapping), selain itu juga diperlukan data sekunder yang meliputi kasus Leptospirosis tahun 2017, letak geografis Desa Banjarpanepen , Kecamatan Sumpiuh, Kabupaten Banyumas, batas wilayah Desa Banjarpanepen, Kecamatan Sumpiuh, Kabupaten Banyumas.

Pengolahan data dilakukan dengan cara editing, yaitu kegiatan pengecekan data dan mengoreksi seluruh data yang telah masuk untuk mencegah terjadinya kekeliruan data. Coding, yaitu kegiatan pengelompokan data dan atau pemberian kode pada hasil pengamatan dan pengukuran yang telah terkumpul untuk memudahkan dalam pengolahan data. Tabulating, yaitu kegiatan memasukan dan atau pengelompokan data ke dalam bentuk tabel.
Analisis data dalam penelitian ini adalah analisis tabel yaitu setelah data terbentuk dalam tabel kemudian di dianalisis secara deskriptif dan dikaitkan dengan teori yang relevan.

Etika penelitian yang digunakan adalah Informed Consent (Lembar Persetujuan), yaitu lembar persetujuan akan diberikan subyek penelitian yang akan diteliti untuk meminta izin melakukan penelitian. Peneliti tidak dapat melakukan penelitian apabila tidak diberikan izin oleh responden. Jika responden menolak untuk diteliti maka peneliti tidak akan memaksa dan tetap menghormati hak-haknya. Anonimity (Tanpa Nama), yaitu kerahasiaan identitas responden perlu dijaga oleh peneliti dan tidak mencantumkan nama pada lembar pengumpulan data. Nama dicantumkan dalam inisial huruf kemudian lembar tersebut hanya diberi nomor kode tertentu saja. Confidentaly, yaitu Informasi yang dikumpulkan dijamin kerahasiaan dan tidak dipublikasikan hanya digunakan untuk mendukung penelitian yang dilakukan oleh peneliti.

\section{HASIL DAN PEMBAHASAN}

\section{A. Gambaran Kasus Leptospirosis}

\section{Kasus Leptospirosis di Kabupaten Banyumas.}

Kasus Leptospirosis menyebar di berbagai daerah salah satunya adalah Kabupaten Banyumas. Wilayah Kabupaten Banyumas ditemukan kasus Leptospirosis sebanyak 66 kasus dan tercatat 8 angka kematian pada tahun 2017. Kasus tersebut diantaranya terletak pada Kecamatan Banyumas yang tercatat 2 kematian, Kecamatan Cilongok 2 kematian, dan terbanyak pada Kecamatan Sumpiuh yaitu 4 kematian. Kasus Leptospirosis di Kecamatan Sumpiuh tercatat 9 kasus dengan 4 angka kematian yang tepatnya berada di Desa Banjarpanepen yaitu 2 kematian dan 1 kematian berada di Desa Ketanda dan Desa Boganging.

\section{Kasus Leptospirosis di Kecamatan Sumpiuh.}

Kecamatan Sumpiuh adalah wilayah dengan angka kematian tertinggi akibat penyakit Leptospirosis di Kabupaten Banyumas dengan jumlah 4 kematian yang tersebar dibeberapa daerah. Data dapat dilihat pada gambar berikut : 
-Sembuh Meninggal

22

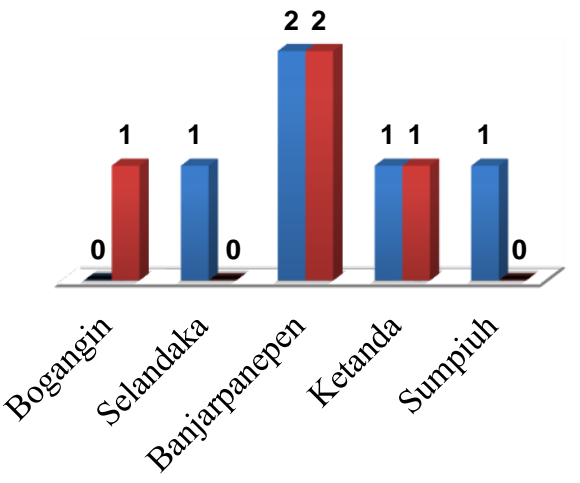

Gambar 4. 1 Grafik jumlah angka kematian akibat leptospirosis di kecamatan Sumpiuh Tahun 2017.

Dari data diatas, dapat diketahui bahwa kasus Leptospirosis di wilayah Kecamatan Sumpiuh tersebar di beberapa Desa, yaitu Desa Bogangin dengan 1 kasus dan 1 kematian, Desa Selandaka 1 kasus, Desa Banjarpanepen 4 kasus dengan 2 kematian, Desa Ketanda 2 kasus dengan 1 kematian, dan Desa Sumpiuh 1 kasus.

\section{Jenis Umpan}

Jenis umpan yang digunakan dalam pemasangan perangkap tikus di Desa Banjarpanepen, Kecamatan Sumpiuh, Kabupaten Banyumas yaitu kelapa bakar. Hasil penelitian yang dilakukan oleh Untung Riyadi di Perumahan Tanjung Elok Kecamatan Purwokerto Selatan Kabupaten Banyumas menunjukkan dari 84 perangkap yang dipasang didapatkan ada 12 tikus yang tertangkap. Lima tikus tertangkap pada perangkap dengan umpan rodentisida " $X$ " sedangkan tujuh tikus tertangkap pada umpan yang berisi kelapa bakar. Tikus yang tertangkap berjenis Rattus-rattus diardi dan Rattus argentiventer. Dari hasil penelitian tersebut, kelapa bakar menjadi pilihan untuk dijadikan umpan dalam penelitian ini. Jenis Perangkap

Jenis perangkap yang digunakan dalam pemasangan perangkap tikus di Desa Banjarpanepen, Kecamatan Sumpiuh, Kabupaten Banyumas yaitu life trap atau perangkap hidup. Perangkap tersebut terbuat dari besi dan berbentuk persegi panjang, jenis life trap atau perangkap hidup digunakan untuk mendapatkan tikus yang masih hidup guna mengidentifikasi baik spesies tikus maupun ektoparasit dan endoparasit yang berada pada tikus.

Jumlah Perangkap yang dipasang
Pemasangan perangkap tikus dilakukan pada tanggal 7-10 Mei 2018, perangkap dipasang pada sore hari yaitu pada pukul 15:00-17:00 WIB kemudian diambil keesokan harinya pada pukul 06:00 WIB selama 4 hari berturut-turut. Jumlah perangkap yang dipasang sebanyak 200 perangkap, dengan pembagian 120 perangkap untuk 60 rumah yang berada di RT 1 RW 4 dan 80 perangkap untuk 40 rumah yang berada di RT 1 RW 8. Setiap rumah dipasang 2 perangkap yang lokasinya berada didapur dan halaman sekitar rumah selama 4 hari berturut-turut.

Tata Cara Pemasangan Perangkap Tikus Sebelum memasang perangkap tikus, hal yang harus diperhatikan adalah penentuan lokasi dan pastikan perangkap tikus tersebut dalam keadaan bersih atau dibersihkan terlebih dahulu guna menghilangkan bekas atau bau tikus, kemudian pasang umpan kelapa bakar yang telah di siapkan sebelumnya dan gunakan sarung tangan ketika memasang umpan tersebut. Langkah selanjutnya adalah persiapan pendistribusian dengan mengikat perangkap tikus yang sudah terisi umpan kelapa bakar, kemudian diikat dengan menggunakan tali atau karet untuk mempermudah dalam distribusinya. Pemasangan perangkap tikus dilakukan pada tanggal 7-10 Mei 2018, perangkap dipasang pada lokasi yang telah ditentukan sesuai dengan tanda keberadaan tikus. Perangkap dipasang pada sore hari yaitu pada pukul 15:00-17:00 WIB kemudian diambil keesokan harinya pada pukul 06:00 WIB selama 4 hari berturut-turut. Hal yang harus diperhatikan saat menempatkan perangkap yaitu lokasi perangkap, penggunaan sarung tangan saat memasang umpan dan tanda keberadaan tikus serta perangkap harus diberi label untuk mempermudah dalam penelitian

Lokasi Pemasangan Perangkap

Lokasi pemasangan perangkap di Desa Banjarpanepen, Kecamatan Sumpiuh, Kabupaten Banyumas yaitu berada di RT 1 RW 4 dan RT 1 RW 8

\section{Spesies Tikus yang Tertangkap.} Wilayah RT 1 RW 4

Wilayah RT 1 RW 4 yang berada di Desa Banjarpanepen, Kecamatan Sumpiuh, Kabupaten Banyumas memiliki 120 rumah, setiap rumah diletakkan dua perangkap yang berada di dua lokasi yaitu di dalam rumah dan halaman rumah. Hasil pemasangan perangkap di RT 1 RW 4 adalah sebagai berikut : 
Gambar 4. 2 Grafik jumlah tikus yang tertangkap di wilayah RT 1 RW 4.

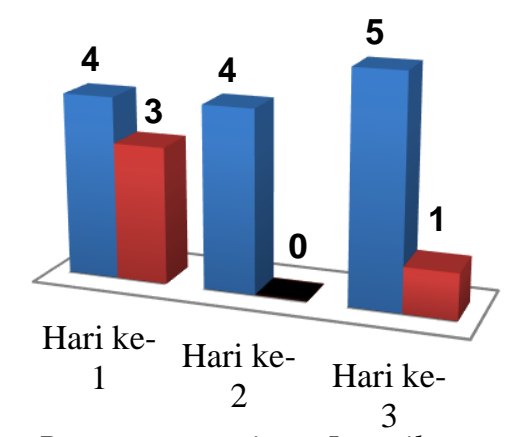

- Rattus tanezumi $\square$ Juvenile

Jumlah tikus yang tertangkap sebagaimana terdapat pada gambar 4. 2 dapat dijelaskan bahwa pemasangan perangkap pada hari ke-1 diperoleh hasil 7 ekor tikus, pada hari ke- 2 diperoleh 4 ekor tikus dan pada hari ke-3 diperoleh hasil sebanyak 6 ekor tikus dari 120 perangkap yang dipasang selama 4 hari yaitu tanggal 7-10 Mei 2018, dengan total sebanyak 17 ekor tikus dan spesies yang tertangkap adalah Rattus tanezumi sejumlah 14 ekor dan Juvenile (tikus muda) sejumlah 3 ekor. Pemasangan perangkap di RT 1 RW 4 sebanyak 120 perangkap dengan Trap succes $14,16 \%$ dan spesies tikus yang berhasil ditangkap adalah Rattus tanezumi 13 ekor (76,47\%), Juvenile 4 ekor (0,24\%).

\section{Wilayah RT 1 RW 8}

Wilayah RT 1 RW 8 yang berada di Desa Banjarpanepen, Kecamatan Sumpiuh, Kabupaten Banyumas memiliki 40 rumah, setiap rumah diletakkan dua perangkap yang berada di dua lokasi yaitu di dalam rumah dan halaman rumah. Hasil pemasangan perangkap di RT 1 RW 8 adalah sebagai berikut :

\section{$\square$ Rattus tanezumi $\square$ Juvenile}

- Subadult

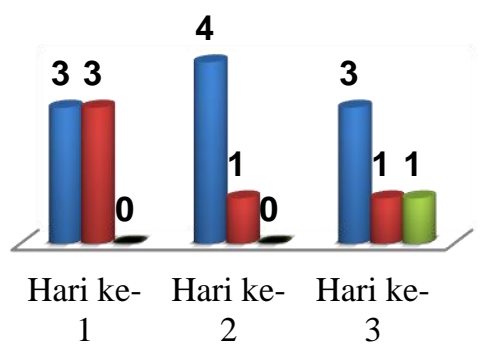

Gambar 4. 3 Grafik jumlah tikus yang tertangkap di wilayah RT 1 RW 8.
Jumlah tikus yang tertangkap sebagaimana terdapat pada gambar 4. 3 dapat di jelaskan bahwa pemasangan perangkap pada hari ke-1 diperoleh hasil 6 ekor tikus, hari ke-2 diperoleh 5 ekor tikus dan pada hari ke-3 diperoleh hasil sebanyak 5 ekor tikus dari 80 perangkap yang dipasang selama 4 hari yaitu tanggal 7-10 Mei 2018, dengan total sebanyak 16 ekor tikus dan spesies yang tertangkap adalah 10 ekor spesies Rattus tanezumi, Juvenile (tikus muda) sejumlah 5 ekor, Subadult (tikus remaja) sejumlah 1 ekor. Hasil yang diperoleh di RT 1 RW 8 yang dipasang sebanyak 80 perangkap dengan Trap succes $20 \%$ dan spesies tikus yang berhasil ditangkap adalah Rattus tanezumi sejumlah 10 ekor (62,5\%), Juvenile (tikus muda) sejumlah 5 ekor $(31,25 \%)$, dan Subadult (tikus remaja) sejumlah 1 ekor $(6,25 \%)$. Tikus merupakan salah satu binatang yang mempunyai kontribuasi terhadap penyebaran penyakit Leptospirosis. Hasil penelitian sebelumnya telah melakukan penangkapan tikus yang dilakukan pada empat lokasi (Tridonorejo A, Tridonorejo B, Moro dan Sumberejo) di Kecamatan Bonang. Hasil penangkapan menunjukkan bahwa trap succes pada daerah tersebut tinggi $(>7 \%)$. Jenis tikus yang tertangkap di 4 wilayah adalah tikus rumah atau Rattus tanezumi yaitu sebanyak 159 ekor, jenis kelamin R.tanezumi betina 50,31\%, jantan $32,70 \%$ dan muda 16, $98 \%$. Dengan demikian keberadan tikus perlu dilakukan pengendalian agar tidak menjadi perantara penyebaran Leptospirosis.

Brooks, G.F et al.(2001, h. 9) menyebutkan bahwa tingkatan trap success di pemukiman tergolong tinggi apabila lebih dari tujuh persen. Lingkungan luar (sawah) tergolong tinggi apabila lebih dari dua persen. Oleh karena itu trap succes pada penangkapan tikus yang dilaksanakan di RT 1 RW 4 dan RT 1 RW 8 Desa Banjarpanepen tergolong tinggi dan perlu dilakukan pengendalian guna menurunkan angka kematian akibat Leptospirosis.

Menurut Suyanto, tikus rumah $R$. tanezumi merupakan sinonim dari Mus diardii, habitatnya di rumah, tersebar luas di Indonesia, Malaysia, dan Thailand. Tikus rumah $R$. tanezumi dikenal sebagai tikus komensal (commensal rodent atau synanthropic), karena seluruh aktivitas hidupnya, seperti mencari makan, berlindung, bersarang, dan berkembang biak dilakukan di dalam rumah. Tikus ini berperan penting dalam penularan beberapa penyakit seperti pes, leptospirosis, dan 
penyakit cacing nematoda. Adanya tikus yang tertangkap di dalam rumah mengindikasikan lingkungan rumah yang tidak sehat.

Hasil penelitian Sarkar, menyebutkan bahwa melihat tikus di dalam rumah beresiko 4,5 kali lebih besar untuk terjadi Leptospirosis. Infeksi bakteri Leptospira $s p$. terjadi karena kondisi lingkungan perumahan yang banyak dijumpai tikus, sehingga bila terjadi kontaminasi oleh urin tikus yang mengandung bakteri dapat dengan mudah terjangkit penyakit Leptospirosis. Menurut Brook dan Rowe 1982, tikus rumah R.tanezumi beraktivitas, berkembangbiak, bersarang, dan mencari makan di lingkungan manusia.

Identifikasi tikus perlu di perhatikan ciri khas morfologi masing-masing jenis tikus, bagian-bagian tubuh yang digunakan sebagai kunci identifikasi seperti Panjang kepala dan panjang badan yaitu diukur dari moncong sampai ke anus, disingkat dengan $\mathrm{H}$ dan B (Head dan Body). Panjang ekor yaitu diukur dari anus sampai ujung ekor dan dinyatakan dalam milimeter serta disingkat dengan T (Tail). Panjang telapak kaki belakang, diukur dari ujung tumit sampai ke ujung kuku (cakar), disingkat dengan HF(Hind Foot). Panjang telinga yaitu dari tabik (legokan/lekukan) pada dasar telinga sampai ke ujung daun telinga, disingkat dengan E (Ear). Panjang tengkorak tikus, dimulai dari ujung tonjolan di belakang kepala sampai ke ujung tulang hidung disingkat dengan Sk (Skull). Disamping mengetahui ukuran bagianbagian tubuh tersebut perlu pula diketahui susunan putting susunya. Puting susunya tersusun dalam dua kelompok yaitu bagian depan atau bagian anterior (pectoral mammae) dan bagian belakang atau bagian posterior (pelvic/abdominal mammae). Rumus dari susunan susu tersebut ditulis dengan menyatakan beberapa pasang bagian belakang (perut) dan jumlahnya tidak dinyatakan dalam pasangan tapi dalam satuan (Harrison,1962)(Chasan S Kusnandi, 2006).

Bagian tubuh yang paling menonjol untuk dapat diidentifikasi terlebih dahulu dapat berbeda pada masing-masing spesies. Identifikasi tersebut menghindari kesalahan dalam identifikasi karena kunci identifikasi hanya menyebutkan karakteristik sepesies pada ukuran dewasa. Ciri khas spesies Rattus tanezumi yaitu kepala dan badan lebih pendek dari pada ekornya dan tidak mencicit serta warna bulu abu-abu gelap dan abu-abu kecoklatan/kusam.

Jumlah Tikus yang Tertangkap Berdasarkan Jenis Kelamin.

Tabel 2.1 Perbedaan antara gas HCN dan $\mathrm{CH}_{3} \mathrm{Br}$

\begin{tabular}{|c|c|c|c|c|c|c|}
\hline \multirow[b]{2}{*}{$\begin{array}{l}\mathrm{N} \\
\mathrm{O}\end{array}$} & \multirow[b]{2}{*}{$\begin{array}{c}\text { Lokasi } \\
\text { Perang } \\
\text { kap }\end{array}$} & \multirow[b]{2}{*}{$\begin{array}{c}\text { Jumlah } \\
\text { Perang } \\
\text { kap }\end{array}$} & \multicolumn{2}{|c|}{$\begin{array}{c}\text { Jenis } \\
\text { Kelamin }\end{array}$} & \multirow[b]{2}{*}{ Spesies } & \multirow[b]{2}{*}{$\begin{array}{c}\text { Juml } \\
\text { ah } \\
(\text { ekor } \\
\text { ) }\end{array}$} \\
\hline & & & $\pi$ & Q & & \\
\hline 1 & $\begin{array}{l}\text { Dalam } \\
\text { rumah }\end{array}$ & 100 & 8 & 10 & $\begin{array}{l}R . \\
\text { tanezumi }\end{array}$ & 18 \\
\hline 2 & $\begin{array}{l}\text { Halam } \\
\text { an } \\
\text { rumah }\end{array}$ & 100 & 3 & 12 & $\begin{array}{l}R . \\
\text { tanezumi }\end{array}$ & 15 \\
\hline \multicolumn{2}{|c|}{ Total } & & 11 & 22 & & 33 \\
\hline
\end{tabular}
berdasarkan jenis kelamin sebagaimana terdapat pada table dapat dijelaskan bahwa dari 200 perangkap yang dipasang, tikus betina jumlahnya dua kali lebih besar dari tikus jantan yaitu 22 ekor (11\%) tikus betina, sedangkan tikus berjenis kelamin jantan 11 ekor $(5,5 \%)$. Tikus jantan lebih banyak ditemukan berada di dalam rumah, sedangkan tikus betina diluar rumah (halaman rumah). Hasil yang diperoleh dari 200 perangkap yang dipasang, tikus betina jumlahnya jauh lebih besar yaitu 22 ekor (11\%), sedangkan tikus berjenis kelamin jantan 11 ekor (5,5\%). Priyambodo menyatakan bahwa tikus berjenis kelamin betina lebih sering berada diluar rumah untuk mencari makan bagi anak-anaknya, sedangkan tikus berkelamin jantan lebih sering berada disarang untuk mempertahankan daerahnya. Tikus jantan lebih banyak ditemukan berada di dalam rumah, sedangkan tikus betina diluar rumah (halaman rumah) dan spesies yang tertangkap di Desa Banjarpanepen, Kecamatan Sumpiuh, Kabupaten Banyumas adalah Rattus tanezumi.

\section{KESIMPULAN}

Berdasarkan hasil penelitian tentang Deskripsi Jumlah dan Spesies Tikus Di Desa Banjarpanepen, Kecamatan Sumpiuh, Kabupaten Banyumas, Tahun 2018 dapat diambil kesimpulan sebagai berikut :

Kasus Leptospirosis di Desa Banjarpanepen tercatat 4 kasus dengan 2 kematian di RT 1 RW 8 dan RT 1 RW 4 yang terkena kasus Leptospirosis 2 dari 4 penderita bekerja sebagai penderes gula merah dan tebu karena masyarakat yang tidak menggunakan alas kaki selama bekerja dan terinfeksi bakteri Leptospira melalui kontak dengan air atau 
makanan. Hasil pemasangan perangkap tikus di RT 1 RW 4 Desa Banjarpanepen menunjukkan bahwa dari 120 perangkap tikus yang di pasang dengan Succes trap 14,16\% dan di RT 1 RW 8 dengan Succes trap $20 \%$ dari 80 perangkap. Jumlah tikus hasil tangkapan di Desa Banjarpanepen sebanyak $16,5 \%$ dari 200 perangkap yang di pasang selama 4 hari. Succes trap pada penangkapan tikus termasuk ke dalam kategori tinggi, karena lebih dari $7 \%$ yaitu $16,5 \%$ dan Spesies tikus yang tertangkap di wilayah RT 1 RW 4 adalah Rattus tanezumi 13 ekor (76,47\%), Juvenile 4 ekor (0,24\%). Spesies tikus yang tertangkap di wilayah RT 1 RW 8 adalah Rattus tanezumi sebanyak 10 ekor $(62,5 \%)$, Juvenile (tikus muda) sebanyak 5 ekor $(31,25 \%)$, dan Subadult (tikus remaja) sebanyak 1 ekor $(6,25 \%)$.

\section{SARAN}

Saran untuk Dinas Kesehatan Kabupaten Banyumas yaitu lebih meningkatkan upaya pencegahan dan penanggulangan penyakit Leptospirosis melalui kegiatan penyuluhan dan monitoring terhadap keberadaan dan menurunkan angka kematian akibat penyakit tersebut. Meningkatkan upaya pengendalian guna mencegah penyebaran habitat yang luas dan pemeriksaan bakteri Leptospira sp pada tikus dan lingkungan serta hewan domestik dengan melibatkan dinas peternakan dan pertanian setempat sehingga dapat terdeteksi jalur penularan Leptospirosis di wilayah Desa Banjarpanepen.

Saran untuk masyarakat yaitu masyarakat harus menerapkan perilaku hidup bersih dan sehat serta meningkatkan kesadaran akan pentingnya hygiene sanitasi guna mencegah tikus untuk berada didalam rumah dengan cara melakukan pengendalian secara fisik atau mekanik sehingga dapat terhindar dari penyakit yang ditularkan oleh tikus.

Saran untuk peneliti lain yaitu peneliti lain dapat melakukan penelitian tentang bakteri Leptospira sp pada tikus dan lingkungan.

\section{UCAPAN TERIMA KASIH}

Terima kasih disampaikan kepada Dinas Kesehatan Kabupaten Banyumas, Seluruh penduduk Desa Banjarpanepen, serta pihak pihak yang terkait sehingga penelitian ini dapat terlaksanakan.

\section{DAFTAR PUSTAKA}

Adil Ustiawan, Sri Hartini, dan Dhian Dwibadra, 2011. Jenis Pinjal dan Inang Di Indonesia. Banjarnegara : Balai Litbang P2B2 Banjarnegara. At http://ejournal.litbang.depkes.go.id/inde x.php/blb/article/view/3316, diakses pada tanggal 10 November 2017

Arief Mulyono, Farida DH, Noor Soesanti H, 2013. "HISPATOLOGI HEPAR TIKUS RUMAH (RATTus TanEzumI) INFEKTIF PATOGENIKLEptTospIRAspp”. Jurnal Vektor dan Reservoir Penyakit. Vol. 5, No. 1 Juni 2013.

Aplin KP, Brown J, Jacob CJ, Krebs, Singleton GR, 2003. Field methods for rodent studies in Asia and the Indo-Pacific. Canberra : Australian Centre for International Agricultural Research.

Ardi Al-Maqassary, Penyakit Yang Disebabkan Oleh Tikus. at http://www.ejurnal.com/2014/02/ penyakit-yangdisebabkan-oleh-tikus.html, diakses pada tanggal 7 November 2017.

Balai Litbang, 2015. Pedoman Pengumpulan Data Reservoir (Tikus) di Lapangan, Jakarta. Badan Penelitian dan Pengembangan Kesehatan Kementerian Kesehatan RI.

Brooks, G.F and S.A. Morse, 2001, Mikrobiologi Untuk Profesi Kesehatan, Jakarta: Buku Kedokteran

CH Erni Kartikawati, 2012, Awas!!! Leptospirosis (Penyakit Yang ditularkan oleh Tikus), Bandarjo-Ungaran: VMedia

Chasan S, Kusnandi, 2006. Pengendalian vektor dan binatang pengganggu (Vektor Control Manual), Makasar: Poltekkes Kesehatan Lingkungan Makasar

Departemen Kesehatan, 2008, Pedoman pengendalian Tikus (Khusus di Rumah Sakit), Jakarta: Dit.Jen. PP \& PL Depkes RIDepkes RI. 2013. Petunjuk Teknis Upaya Pengendalian Penyakit dan Penyehatan Lingkungan dalam Penanggulangan Bencana. Jakarta : Bhakti Husada. 
Departemen Kesehatan, 2005, Pedoman Diagnosa Penata Laksanaan Kasus Penanggulangan Leptospirosis di Indonesia, Jakarta: Sub. Direktorat Zoonosis. Dit. Jen PP \& PL DepKes RI.

Departemen Kesehatan, 2002, Buku Pedoman Pengendalian Tikus, Jakarta:Dit. Jen. PPM dan PL.

Departemen Kesehatan, 2000, Petunjuk pemberantasan Pes di Indonesia, Jakarta: Ditjen PPM \& PL.

Emy Rahmawati. 2012. Partisipasi Ibu Dalam Pemasangan Life Trap Terhadap Jumlah Tangkapan Tikus Dan Pinjal. Jurnal KESMAS, 8 (1): 94-98 Jawetz, Melnick dan Adelbergs. 2005. Mikrobiologi Kedokteran. Jakarta: Salemba Medika.

Identifikasi Tikus, Tim Balai Litbang P2B2 Banjarnegara. www.academia.edu/5546639/identifikas i_tikus, diakses pada tanggal 7 Januari 2018, pukul 09.00 WIB.

Kuswati, Suhartono, Nurjazuli, 2016. Distribusi Kasus Leptospirosis di Kabupaten Demak Jawa Tengah. Jurnal Kesehatan Indonesia.

Makalah Pengendalian Vektor "Jenis-jenis, Penyakit dan Pengendalian Tikus". At http://nistyadya.blogspot.co.id/2013/12/ makalah-pengendalian-vektor-jenisjenis.html, diakses pada tanggal 7 November 2017.

Menkes RI, 1999, Keputusan Menteri Kesehatan Republik Indonesia No. 829/Menkes/SK/VII/1999 tentang Persyaratan Kesehatan Perumahan, Jakarta.

Ririh Yudahastuti, 2011, Pengendalian Vektor dan Rodent, Surabaya : Pustaka Melati Adang Iskandar et all (1985).

Resi, Aneka Saputra, 2015, Identifikasi, Kepadatan Dan Ektoparasit Tikus di Daerah Perimeter, Buffer Dan Permukiman Terdekat Kkp Kelas II Cilacap Tahun 2015, Purwokerto: Poltekkes Kemenkes Semarang.
Sarkar U, Nascimento SF, Barbosa R, Matrins R, Nuevo H, Kalofonos I, et al, 2002. Population-based case-control invertigation of risk factors for leptospirosis during an urban epidemic. American Journal Tropical Medicine and Hygiene. 2002; 66 (5): 605-10.

Simpuh, Sofatun Marwah, 2013, Pengendalian Tikus di Daerah Perimeter Kantor Kesehatan Pelabuhan Kelas II Cilacap Tahun 2010-2012, Purwokerto: Poltekkes Semarang.

Soedjajadi Keman. 2005. Kesehatan Perumahan, JURNAL KESEHATAN LINGKUNGAN, VOL. 2, NO. 1, JULI $2005: 29-42$

Suyanto A, 2004. Mammals of Gunung Halimun National Park, west Java. Bogor : Lembaga Ilmu Pengetahuan Indonesia. Penelitian Biologi.

Swastiko Priyambodo, 1995, Pengendalian Hama Tikus Terpadu, Jakarta : Penebar Swadaya

Tri Cahyono, 2018. Panduan Penulisan Tugas Akhir. Purwokerto: Kementerian Kesehatan RI Politeknik Kesehatan Kemenkes Semarang Jurusan Kesehatan Lingkungan

Tri Ramadhani, Bambang Yunianto, 2012. Reservoir dan Kasus Leptospirosis di Wilayah Kejadian Luar Biasa. Jurnal Kesehatan Masyarakat, Vol. 7, No. 4, November 2012.

Yuliadi, B. 2016. Persebaran Dan Morfometri Tikus Serta Kelelawar Di Indonesia. Salatiga. Riset Khusus Vektor dan Reservoir Penyakit. B2P2VRP 